\title{
Antipodean Aesthetics, Public Policy and the Museum
}

\section{Ben Dibley}

\section{Introduction}

The Museum of New Zealand-Te Papa Tongarewa has proved a complex cultural site that has generated much public debate and a growing academic literature. In this essay I depart from critical approaches that resolve the analysis of this museum by pointing out its programmatic inconsistencies, internal contradictions, representational inadequacies or its institutional paradoxes. ${ }^{1}$ While these formulations do get at matters important to the operations of Te Papa, what is striking in these analyses is that the museum somehow always disappoints the critic by not living up to its stated aims or some ideal of the museum form. ${ }^{2}$ Rather than establishing Te Papa as an object for reform as these critics have done, I read it as an archive for reflection on the cultural predicament of an antipodean modernity. ${ }^{3}$ To this end this essay proceeds by initially establishing the wider movements in which the institution is located. Then it maps how these movements have shaped the museum's formulations and its reception by focusing on the period leading up to its opening. Finally, it considers a particular antipodean style of representation associated with these movements. In this context, I conclude, Te Papa might best be understood as a monument to 'antipodean camp'. ${ }^{4}$

Before entering into a discussion of the museum proper it is helpful to sketch the pressures shaping the wider economic, social, political and cultural scapes whose contours marked Aotearoa/New Zealand (A/NZ) in the closing decades of the last century; the period in which Te Papa was conceived and came into operation as a public institution. ${ }^{5}$ Principally this 
concerns the accumulation crisis that drove the restructuring of the nation's economy according to the dictates of global capital and a correlated discursive project which sought to reinvent the national community in its wake. Here, as elsewhere, in the face of the historic failure of the import-substitution tradition, an economic-political project embracing neoliberalism was advanced. In $\mathrm{A} / \mathrm{NZ}$ this was contemporaneous with a particular socio-cultural project that sought to reinvent the national community in a postcolonial image which has gone by the name of biculturalism.

\section{Restructuring}

Following a twenty-year period of economic decline, exacerbated by the loss of the country's traditional market for agricultural products when Britain joined the European Economic Community (EEC) in 1973 and by the OPEC shocks beginning the same year, A/NZ's unemployment, inflation and public debt by the 1980 os had spiralled to levels unprecedented in the postwar period. By the mid 1980s the import-substitution policies that sought to protect the domestic economy from the vagaries of global capital flows had all but run their course. Driven by the imperatives of this global transformation in the regime of accumulation and by the rhetoric of neoliberal public policy, there followed a rapid dismantling of the legislative shock absorbers of the domestic defence tradition, which subsequently exposed the country to the full force of the world economy. In a relatively short period A/NZ's economy was transformed from one of the most highly regulated in the world to one of the least regulated. Domestic production came to be dominated by international money markets, large corporations and international speculators, in particular those from Australia, Japan and South-East Asia. Labour market legislation individualised employment contracts between employers and workers, and changes to immigration legislation encouraged wealthy and highly skilled immigrants from 'non-traditional source countries' to counter negative migration and encourage investment. Substantive steps were also made towards the dismantling of the welfare state. Ironically enough, it was following the election of the Fourth Labour government in 1984 that A/NZ made this switch to 
Thatcherism, initiating a restructuring program in which the old 'laboratory of welfare statism' was to be transformed into the new 'laboratory of economic rationalism'. ${ }^{6}$ Celebrated by The Economist, among others, the New Zealand Experiment, as Jane Kelsey labelled it, was for a time widely advocated by neoliberal economic and public policy analysts as a model for the world to follow.

The once pervasive discourse of an utopic little Britain in the South Seas - liberated from the class inequalities of the Old World and free from the racial injustices of much of the New World (expressed in the popular refrain 'the best race relations in the world') - became an increasingly unsustainable settler mythos following these transformations in the regime of accumulation. As Simon During observed: the 'strategies of state minimalization, deregulation, orientation to global, and especially East Asian, markets fractured the colony's hegemonic, if blind, understanding of itself as an outpost of British culture and civility'. ${ }^{7}$ Nevertheless, the ideologues of neoliberalism made a direct assault on the residue of this once pervasive myth, arguing that it was 'the culture' that was holding the country back from accelerated economic growth. The Porter Project (a state sponsored neoliberal think tank), for example, stated: New Zealand's only constraint to achieving its potential was the 'people's inability or unwillingness to adapt, change and thus compete successfully in the global economy'. ${ }^{8}$ This concern to install a neoliberal ethos in the citizenry aimed to move 'the culture' from one of egalitarianism and 'welfare dependency' to an internationally viable 'Enterprise Culture' based on competitive individualism. It also sought a cultural change in regional orientation away from the old economies that had so painfully rejected the country, towards the new economies of the Asia-Pacific rim through which its future might hopefully be secured.

\section{Biculturalism}

The downturn in the market for A/NZ's agricultural production, along with the abandonment of domestic defence policies of import-substitution that promoted a local manufacturing sector, increasingly propelled rural Maori into the ranks of the urban working class. This process had 
begun in the 1950 and accelerated over the 1960 s and 1970s, leading to the disembedding of many Maori from their tribal affiliations. Facilitating this process and all the while seeking to ameliorate social fragmentation, was the welfarist policy of assimilation. Here Maori were to be progressively 'raised' to the level of Pakeha (settler heirs) through policies in education, health, housing and social welfare. Assimilation remained the dominant model of social policy until the late 1970s. The situation of tribal disembedding and institutional racism gave rise to a resurgent anti-colonial activism over the late 1970 and 1980s. ${ }^{9}$ Significantly, this political movement secured the legal recognition of the 1840 Treaty of Waitangi that the British Crown had signed with Maori chiefs to regulate relations between Indigenous communities and European settlement. Although the Waitangi Tribunal was initially established in 1975, it was not until the passing of the Treaty of Waitangi Amendment Act in 1985 that the Treaty was officially acknowledged and the Tribunal was given the power to investigate Maori claims of injustice and loss back to 1840 . From the early 1990s, government policy developed to acknowledge past wrongs and to supply compensation to recapitalise tribes. ${ }^{10}$

Associated with this development was a wider project which sought to acknowledge and bridge the economic, social and cultural fault-lines of a nation whose inheritance was forged in the violence of an earlier globalising movement of capital: nineteenth century British colonisation. To rekindle, for Pakeha at least, good faith in the future possibility of harmonious race relations, a prominent and increasingly state sanctioned discourse of biculturalism announced its utility. Imported from Canada, the concept began to be used in academic circles from the late $1960 s .{ }^{11}$ From the mid 1980 it has increasingly been advocated in public policy and has emerged as a legislative practice of compensation for Maori. It has also served as a discursive practice of reconciliation, to promote a new 'postcolonial' national imagining. This has seen the Treaty of Waitangi recognised, not only as the basis for Maori to seek redress for loss and injustice, but as the constitutional origin of the nation, being increasingly articulated as such in public culture over the 1980 s and $1990{ }^{12}$ Here, anti-colonial efforts by Maori to reassert aspects of their traditional culture 
and political autonomy, have given rise to a socially liberal desire among Pakeha to reinvent the national imagining and 'change the culture' (in ways that are not theoretically, historically and politically unproblematic) from the colonial to the postcolonial. ${ }^{13}$

Unsurprisingly, the relationship between the processes of economic restructuring that forced the hegemony of a utopic little Britain to fragment, and the project of biculturalism that emerged to replace it, has been contentious. For many commentators of the time, restructuring and biculturalism appeared to be deeply antagonistic agendas. Wendy Larner and Paul Spoonley, for example, enthusiastically emphasised biculturalism's progressive potential:

Biculturalism in Aotearoa/New Zealand provides a powerful expression of progressive and inclusive forms of politics based on self-defined identities and reflecting local sensitivities ... [It] provides one of the most effective counters to New Right ideologies and the harsh realities of the monetarist experiment based on market competition and individualism. ${ }^{14}$

Other commentators conceded it was not a coincidental conjuncture that as $\mathrm{A} / \mathrm{NZ}$ became increasingly assimilated into a new regime of global economics and cultural politics it simultaneously became 'more sensitive to [cultural] differences'. For example, cultural critic Mark Williams found biculturalism rather less oppositional. More cautiously, he wrote, 'biculturalism has clearly been advantageous in fashioning an acceptable national self-image in a world where colonialism and racism are bad for business'. ${ }^{15}$

\section{Te Papa}

In 1993, shortly after her appointment as CEO for the new museum project, Cheryll Sotheran acknowledged the mission with which the state had charged her institution. ${ }^{16}$ Embracing the logic of public sector restructuring, she was to deliver a museum product that would generate a wide audience, while 'bedding down' biculturalism within the institution. Presciently, Sotheran announced that when it eventually 
opened, the museum would be 'as popular, in Kiwi terms, as Disneyland'. ${ }^{17}$ This rhetoric confirmed that the legislative authority was purchasing an 'info-tainment experience', which, if the museum was to fulfil its statutory obligations, must 'create a new audience' whose demographic profile extended traditional patterns of attendance and more adequately mapped the contours of the country's population. Yet this demand for a new expanded audience was only partially motivated by a desire to democratise the museum. For, while making a substantial fiscal investment in the project-a purported NZ\$320 million - the state was making no ongoing commitment to meet the full costs of its operations once the museum opened. Rather, it sought to construct conditions in which the museum would have to market itself to attract the discretionary income of consumers and corporate sponsorship.

In addition to this deliberate policy of under-funding, to further foster this marketisation, both central government and the city council funding commitments were contingent on the museum reaching visitation 'performance targets'. In this policy environment the museum's administrators identified their task as that of 'repositioning' their organisation as part of the entertainment industry. ${ }^{18}$ Here Sotheran opined: 'The great private sector institutions of Disneyland and McDonalds have a lot to teach us.' ${ }^{19}$ The museum took these lessons very seriously. A themed architectural environment was commissioned that owed as much to fun-park and shopping mall design as it did to museum architecture. ${ }^{20}$ The innovative theme parks, heritage sites and leisure destinations of Europe and North America were toured by senior staff. ${ }^{21}$ US Themed Attraction trade shows were attended and UK leisure industry consultants hired. Multimillion dollar theme park-like rides were invested in. ${ }^{22}$ Front-of-house staff or 'hosts' - a term borrowed from Disney-were comprehensively trained in the 'customer focused' and 'scripted' manner pioneered by Walt Disney and McDonalds founder, Ray Croc. All of which was to facilitate the 'repositioning' of the museum product, which, while entry was to remain free, delivered customers to numerous 'revenue-generating opportunities'. A 'McDisney' service model, then, was to deliver national identity. ${ }^{23}$ In the words 
of its promotional material, the museum would constitute a product 'different from any other museum ... Playful, imaginative, interactive, bold, even cheeky - Te Papa is quintessentially Kiwi, stunningly high-tech, and seriously fun'. ${ }^{24}$

If Disney, in part at least, provided the inspiration for the repositioning of the museum, it was the exhibition Te Maori which provided the catalyst for the 'bedding down' of biculturalism. Te Maori opened at the Metropolitan Museum of Art New York in 1984 and subsequently toured the United States, before returning to $\mathrm{A} / \mathrm{NZ}$ and touring the main centres in $1985 .{ }^{25}$ Famous for its radical aesthetic decontextualisation, Te Maori was a complex event: complex in its organisation, reception and effects. ${ }^{26}$ It was celebrated by some cosmopolitan academics and criticised by others. For James Clifford, Ivan Karp and Steven Lavine it exemplified museological practices by which an indigenous community was able to represent itself on an international stage. ${ }^{27}$ Raymond Corbey read the primitivist reception of the exhibition in the United States as uncomfortably repeating elements of colonial displays of alterity, ${ }^{28}$ while Nicholas Thomas argued that the essentialist elements of Te Maori's primitivism had been used strategically to empowering effect for Maori communities. ${ }^{29}$

Locally, the exhibition was contentious among Maori. There were heated debates as to whether taonga-cultural treasures - should tour the United States. Communities were divided over the exploitation of taonga as art in a major foreign institution: should taonga remain in a context in which they had mana - power and prestige - and a nonaesthetic function, or should they be used to communicate Maori culture and skills to a wider audience and increase Maori international prestige?30 The experiences of local museums in organising this exhibition were salutary and led to widespread recognition that such institutions needed to dramatically renegotiate their relationship with their Maori constituencies. ${ }^{31} \mathrm{On}$ its return tour of $\mathrm{A} / \mathrm{NZ}$ the collection of taonga, each imbued with complex tribal associations, caused unprecedented issues of protocol for tribal Maori as they negotiated their relationship with each other, the tribal lands in which the taonga were rooted and the whakapapa with which they were invested. ${ }^{32}$ For Pakeha, American interest in 
Te Maori was seminal in generating a large national audience for its return home tour. As columnist Rosemary McLeod glossed it, for a broad public the exhibition 'suddenly showed Maori cultural heritage as art as much as artefact, as unique and as a sleeping asset'.33 Published at a time when hundreds of thousands of New Zealanders were flocking to see Te Maori, Nga Taonga o Te Motu: Treasures of the Nation - the report that initiated the Te Papa project-aimed to capitalise on that asset:

The outstanding success of the exhibition Te Maori in the US has demonstrated that the taonga of New Zealand, sensitively presented and appropriately housed, is a potent force in the processes of identifying our culture in all its richness and diversity and enhancing its relevance to all New Zealanders. ${ }^{34}$

In the planning stages of the museum project the processes of 'identifying', 'defining' and 'promoting' 'our culture' saw the development of various mechanisms that would deliver biculturalism. ${ }^{35}$ Conceptually the institution was founded on a threefold division based on the relations the Treaty of Waitangi established between tangata whenua (people of the land), tangata tiviti (people of the treaty) and Papatuanuku (the environment). ${ }^{36}$ Architecturally this was to be expressed in a biculturally themed structure; 'cleaved' - a drawing apart while pulling together - by the space devoted to the Treaty of Waitangi (see below) which also linked the two major exhibition zones given over to Maori and Pakeha exhibitions. ${ }^{37}$ This was to facilitate the exhibitions' articulation in relation to the institution's narrative of bicultural nationalism. Bilingualism was deployed across the institution: Maori language - te reo-alongside English was to be used in all museum labels and signs. However, biculturalism was not to stop at the level of representation. A bicultural organisational structure was implemented, exemplified by the appointment of Cliff Whiting as the museum's kaihautu, which was an institutional position equivalent to that of the CEO. Decision-making processes throughout the planning stages of the project were to involve extensive consultation with $i w i$ on the principle 
(Mana Taonga, discussed below) that those with cultural objects in the museum should contribute to how they are managed and interpreted. In addition, competency in te reo was set as a performance target for all staff..$^{8}$ All of which was to institute 'one of the first public institutions in the country modelled on bicultural commitment'. 39

Sensibly, then, recent analyses of the museum project position it as an 'alternance between neoliberal wisdom and the postmodern vision of Aotearoa/New Zealand's biculturalism ... that has characterised the country in the last two decades'. ${ }^{\circ}$ However, it is interesting to recall that the position of the museum project's relationship to the broader structural and discursive realignments that the country was experiencing was confused in early commentary. While for some it did exemplify a paradigmatic shift in cultural policy contingent on those forces, for others it appeared to embrace an inappropriate nostalgia for the public policies of the protectionist era. For those inclined to read it as harking back to older, superceded policy initiatives, some emphasised its resonances with economic policies of the domestic defence tradition, while others emphasised its affinity with social policies of assimilation.

For some commentators the construction of a state sponsored multimillion dollar theme-park devoted to national identity had resonances with the discredited 'Think Big' policies, which had promoted projects like the hydropower scheme at Clyde that had been the last gasp of the 'domestic defence' tradition. ${ }^{41}$ That the public face of the new museum project was Wallace Rowling, a former Labour leader from the protectionist era, further encouraged the reading of the proposed museum as a public policy anachronism. Certainly, in his efforts to enlist support for the project Rowling did express discontent with the current policy direction, stating: 'a country needs more than monetary policy to weld its people together and create a sense of identity'. ${ }^{42}$ When the finalised plans of the new building were released for public perusal (to a less than warm reception) and details of government expenditure on the project were disclosed (to a scandalised media), the national press ran editorials whose headlines rang with the alarm of a certain deja vu: the Sunday Star warned 
'Another Grandiose Monument to Insanity', while the New Zealand Herald feared 'Think Big Reincarnate'. ${ }^{43}$ For these commentators the project looked like an unwarranted turning away from the tight fiscal policy that two terms of a Labour government had told New Zealanders was the tough medicine that would ultimately be good for them. The hydropower scheme, which was (finally) plugged into the national grid the week the museum project was given the go ahead, was years behind on its projected completion schedule and vastly over budget. Characterising the museum as a massively expensive 'job creation' scheme, commentators declared the 'taxpayer' could not afford a 'Cultural Clyde Dam'.44

Other commentators, less concerned with the museum's apparent nostalgia for superceded economic policy, found it to be a social policy anachronism. A number of commentators were suspicious of the museum's conceptual architecture and its totalising thrust, which they felt threatened to flatten out cultural difference in a mode that disconcertingly appeared to mimic the ambitions of mid-century social policy. Apirana $\mathrm{T}$. Mahuika, architect of the policy-Mana Taonga-governing the museum's relation to Maori material culture, iwi (tribe) and other cultural artefacts, appeared to explicitly articulate this agenda. ${ }^{45}$ Mahuika argued, with 'the Papa Tongarewa concept many Maori tribes have paused a while [with their calls for Maori nationhood] to see what cultural recognition will result from the proposed Museum'. 'Maori disquiet', he continued, 'can be calmed only by a program such as that proposed by Te Papa Tongarewa. ${ }^{\prime 6}$ Unsurprisingly, the protocol that Mahuika designed has been controversial among tribal Maori. Indeed, Te Arawa scholar and museum curator Paul Tapsell has argued that the passing over of the customary lore of local iwi, Te Ati Awa and Ngati Toa, inherent in the Mana Taonga concept, abrogates the museum's obligations to tangata whenua under the Treaty. ${ }^{47}$ In this way the nationalised taonga of Te Papa repeated the colonial injustices experienced by the tangata whenua of the Wellington region..$^{8}$ Luit Bieringa, former director of the National Art Gallery of New Zealand, found the Te Papa concept to be 'an out-dated piece of assimilatory nationalism'. He argued: 
in confusing [cultural] unity with similarity [it] represents an order reminiscent of 1950 s and 1960 s assimilation. Not only does it speak of centralised bureaucracy of the kind being demolished by the present Government, but it is also out of step and shows an insensitivity to the aspirations of ... [Maori] communities. ${ }^{49}$

Cultural critic, and Te Papa curator to be, Ian Wedde, was to argue along similar lines. The museum's concept, he contended, 'runs absolutely counter to Maori culture's fundamental base in tribal regionalism' and was 'surely an anachronism at the turn of the century'. ${ }^{\circ}$

However, unsurprisingly, when in July 1994 Jim Bolger, then the conservative prime minister, unveiled the foundation stone for the new institution with Maori elder, Te Ru Wharehoka, he represented the museum not as an anachronism but as the very symbol of the success of the country's program of structural adjustment and cultural realignment. Addressing his audience, Bolger congratulated himself on his foresight in giving the project the 'go-ahead' in those 'dark days' of the 1992 recession. For him the museum not only announced a new national 'cultural maturity' and 'celebrated', as the inscription on the foundation stone read, 'the many journeys and identities of all the communities and peoples of New Zealand', but it also stood as 'a symbol of the economic recovery' after a long period of decline. ${ }^{51}$ In Bolger's estimation, then, the museum looked to symbolise the cultural and economic reorientation the nation required to successfully compete in the global market place.

Providing some analytical coordinates for Bolger's proposition in an early analysis of the project, cultural policy analyst and former director of the National Museum, Michael Volkerling, argued that the museum represented a paradigmatic shift: as the 'key institution' for 'New Zealand cultural policy' reorientation, the museum marked the 'transition from Fordist to post-Fordist forms of economic and social organisation'. ${ }^{2}$ Exemplifying the 'fondness for spectacle' shared by New Right regimes in periods of economic austerity, Volkerling contended, the project's bicultural 'exotic hybrid' provided the cultural emblem for, and a marketing strategy 
deployed internationally by, 'New Zealand's post-Fordist state'. ${ }^{53}$ While, anticipating Te Papa's CEO's entrepreneurial characterisation of the country's citizenry as 'energetic, cando, determined progressive risk takers', ${ }^{54}$ Volkerling contended that the museum's hailing of the national subject provided 'an ideological sanction of the methodological individualism which underpins its economic strategies'. ${ }^{55}$

If its early commentators were confused with regard to the museum's policy orientation, this perplexity was mirrored by the disorientation of the museum's first visitors. Despite a tense relationship with its public while under development, there can be little doubt that the museum was enthusiastically received in the immediate period after its opening. In the first nine weeks after Te Papa opened in February 1998, it had already received two thirds of its projected annual visitation of 750 ooo (which had been considered by some as hopelessly optimistic). By its first birthday it had exceeded two million visitors. And, if quantitative measures were impressive, so too were its qualitative evaluations, the overwhelming majority of visitors (ninety-three per cent) reporting satisfaction with their 'experience'..$^{6}$ Sotheran had achieved her theme park audience. Yet, while Te Papa's McDisney template sought to deliver for its visitors predictability, via an architecture, design environment and corporate culture that solicits 'the recurrence of reassurance', being physically perplexed and cognitively confused became a frequent, if not the experience for many of the museum's early visitors. ${ }^{77}$ Swiss architect Mario Botta, for example, found Te Papa's interior cluttered and confused.$^{8} \mathrm{He}$ opined: 'It's a labyrinth, not a space ... life is already complicated - why do we have to make it more confused.'59 A post-occupation evaluation of 'the museum experience', conducted several months after opening, indicated that the failure to successfully deliver a coherent space that could be readily negotiated both cognitively and physically was causing distress among visitors. Overwhelmed by the museum's indeterminate narrative and pedestrian flows, these visitors complained they had little choice but to be thrown into an itinerary of 'drifting'. ${ }^{60}$ Echoing this experience, the recently elected Labour Prime Minister, Helen Clark, reported finding the museum's interior 'jumbled and incoherent'. ${ }^{61}$ 
The perplexity of many of the visitors to a museum intended to designate 'Our Place in the World', ${ }^{62}$ might support Hamish McDonald's speculation in the Sydney Morning Herald. He contended that Te Papa emphasised the predicament of New Zealanders - Pakeha at least - who 'fear they are globalising themselves out of existence'. ${ }^{63}$ Perhaps, then, like Fredric Jameson's Bonventure Hotel, Te Papa might stand as a 'symbol and analogue of that even sharper dilemma which is the incapacity of our minds, at least at present, to map the great global multinational and decentred communicational network in which we find ourselves caught as individual subjects'. ${ }^{64}$

While in recent commentaries on Te Papa this line of analysis hasn't been rigorously pursued, considerable criticism has been levelled at the museum's embrace of aesthetic practices that have been designated postmodern. Here the strategies of mockery, irony, and bricolage deployed by the museum are read by its critics as imported rhetoric that 'lampoons' the sincerity of national feeling; ${ }^{65}$ pastiches that undermine the seriousness of high culture; ${ }^{66}$ a frivolity that diminishes the importance of 'disinterested knowledge'; ${ }^{67}$ or, 'an endless circulation of simulacra' that 'deny the traumas of the past'. ${ }^{6}$ While these arguments do highlight important issues to be debated, there is a tendency to read the museum's aesthetics as derivative of certain discourses and practices'the linguistic turn' ${ }^{69}$ or 'the new museology', for example. $7^{7}$ This risks missing what might be the novelty of Te Papa's exhibitions as a particular response to the scapes in which the museum is located. In using these strategies the museum is not simply a local representative of the cultural dominant of late capitalism ${ }^{71}$ nor, while certainly indebted, is it simply derivative of broader intellectual orientations and institutional practices. Rather, I think, its embrace of mockery, irony and bricolage might be the articulation of a distinctive camp style associated with a locally inflected set of cultural practices reflecting the experience of an antipodean modernity.

\section{Camp}

Te Papa's opening exhibitions, which were devoted to the culture of the settler heirs positively, revelled in their own 
artifice. As their titles suggest, the exhibitions flaunt a camp sensibility whose fabrications, I contend, are explicit exercises in both putting on, while pointing out, the manufactured-ness of national culture and identity. These include the ironic distancing of 'Exhibiting Ourselves', the irreverent bricolage of 'Parade', the nostalgic montage of 'Golden Days', and the ambivalent play of 'Signs of a Nation'.

However, what goes unanswered in analyses that suggest that these names are simply strategies imposed by populist “"post-modern" scholarship', is their particular saliency and operation under local conditions. ${ }^{72}$ In his analysis of a particular antipodean cultural sensibility, Nick Perry writes:

Viewed historically, antipodean camp is explicable as a 'post-colonial' aesthetic for the beneficiaries of colonialism. In its classic form it signals the attempt to outflank the cultural categories and control of metropolitan powers without, however, directly confronting either the historical conditions of its own possibility or the counter narratives which the historical pattern continues to generate. ${ }^{73}$

As exercises in putting on, while pointing out, the fabrications of national identity, which steadfastly avoid any direct confrontation with imperialism and its legacies, Te Papa's opening exhibitions on settler culture share in this aesthetic.

This is exemplified in Te Papa's exhibition devoted to the Treaty of Waitangi, 'Signs of a Nation'. This exhibition mediates between the Pakeha and Maori sections of the building and is posited by one of its curators as a 'liminal space between two worlds'.74 This 'cathedral like space' is flanked by two large veneered panels carrying the full text of the Treaty-one a Maori version, the other in English - while a huge suspended glass relief forms its centrepiece. This is composed of enlarged facsimiles of fragments of the Treaty, indexing the document's fraught history. As the exhibit's architect explains: 'The front layer contains all the signatures of the Waitangi document, while the rear layer represents, in moulded and coloured surfaces, the parchment as ravaged by ill treatment and hungry rats'. This display was designed to demonstrate that the Treaty is 'historical, monumental, awe 
inspiring, troublesome ... [and] relevant'. Put succinctly, this 'monumental treatment' sought to 'convey a sense of wonder'. ${ }^{75}$

While Foucault has observed, 'history is that which transforms documents into monuments', ${ }^{76}$ what has been at stake for critics of 'Signs of a Nation' is the waning of historicity that monumentalising entails. While this treatment might aim to evoke wonder at the historical significance and the contemporary ambiguities 'that abound in the current deployment of the treaty', for Paul Walker and Justine Clarke, wonder dissolves into the depthlessness of distraction. 'In the space of Jameson's paradigmatic Bonaventure or the reality of an interior like Te Papa's', they write, 'everyone is distracted, no one is looking. ${ }^{77}$ For Walker and Clarke, 'Signs of a Nation' ironically hails less the citizenry subject of the postcolonial nation-space, and more the distracted subject of the postmodern. Similarly, for others, 'Signs of a Nation' signalled a vacuous-ness in which the originary violence and the continuing trauma of settler colonialism are voided in the interests of the expediencies of the national present. ${ }^{78} \mathrm{It}$ seems, then, for these critics, 'Signs of a Nation' as an exercise in wonder - of feeling history - shares in the processes that Benjamin has characterised as the aestheticising of politics and which Jameson up-dates as the hysterical sublime. ${ }^{79}$ No doubt these are useful coordinates for reading the exhibition as symptomatic of the transforming scapes in which Te Papa's citizens/consumers are located.

Yet, for all this, wonder here perhaps shades less into distraction and more into the self-mockery of antipodean camp. How else to read an exhibition that seeks to aggrandise the inelegant bureaucratic prose of the Treaty's articles, which decidedly lack any of the grandiloquence of, say, the Declaration of Independence that is immortalised in stone in the Washington Memorial? Or, for that matter, an exhibition that seeks to monumentalise, with gigantic simulations of the Treaty fragments, artefacts that will forever lack the aura of the originals that is dramatised with low light and high security at the National Archives. Wonder fails here, not because everyone is distracted, although that might be so, but because of a sensibility that could only entered into wonder in bad faith. It is this insincerity in the face of wonder, not 
distraction, which makes it the target of attentive critics' complaints that it has avoided a direct confrontation with colonial history and its trauma. If it was sincere, the implication seems to be that the pathos of violence and trauma would demand that wonder give way to historical resonance; antipodean camp would - as it hasn't in this exhibition - slide into 'the New Zealand sublime' diagnosed by Jonathan Lamb. ${ }^{80}$

Perry reads the aesthetic practices with which he is concerned as 'Antipodean permutations on the angel of history allegory'. However, the sensibility of these practices shades not into a Germanic melancholy but toward an antipodean camp. This is because cultural identity here, Perry contends, 'is not seen as shaped and limited by the restraining given-ness of the ruins [of modernity], but as derived from the prospects that such debris opens up for future scavenging and bricolage'. ${ }^{81}$ Te Papa's critics have inadvertently acknowledged a quasiBenjaminian 'trash aesthetic', as Denis Dutton does, when he disparages the museum's resemblance to a 'junkshop', and as other commentators have done when they deride Te Papa for its postmodern populism. ${ }^{82}$ What is unacknowledged, however, when it is read simply as a derivative site or an 'obstinately provincial place', is the complexity of the patterning of the sensibility informing Te Papa. This is one that is decisively marked by a Pakeha futurism which fabricates a national identity from the detritus of the global culture industry and the ruins of colonialism. The museum's opening exhibitions, I think, are more adequately understood as a monument to this sensibility, whose complexity is perhaps best comprehended as antipodean camp.

\section{Notes}

1 These approaches are taken respectively by Paul Williams, 'Te Papa: New Zealand's Identity Complex', New Zealand Journal of Art History, 2003, no. 24, pp. 11-24; Senka Božiċ-Vrbančic, 'One Nation, Two Peoples, Many Cultures: Exhibiting Identity at Te Papa Tongarewa', Journal of the Polynesian Society, 2003, vol. 112, no. 3, pp. 295-24; Anna Neill, 'National Culture and the New Museology', in Anna Smith and Lydia Wevers (eds), On Display: New Essays in Cultural Studies, Victoria University Press, Wellington, 2004, pp. 180-96; Amiria Henare, 'Rewriting The Script: Te Papa Tongarewa the Museum of New Zealand', Social Analysis, vol. 48, no 1, 2004, pp. 55-63.

2 See Ben Dibley, 'The Museum's Redemption: Contact Zones, Government, and 
the Limits of Reform', International Journal of Cultural Studies, vol. 8, no. 1, 2005, pp. 5-27.

3 For two different perspectives see Peter Beilharz, Imaging the Antipodes: Culture, Theory and the Visual in the Work of Bernard Smith, Cambridge University Press, Cambridge, 1997; J. G. A. Pocock, 'The Antipodean Perception' in his The Discovery of Islands, Cambridge University Press, Cambridge, 2005, pp. 3-23. Nick Perry, 'Antipodean Camp', in Nick Perry (ed.), Hyperreality and Global Culture, Routledge, London, 1998. The appellation 'Aotearoa/New Zealand' is caught in processes of transliteration and mistranslation that characterise postcolonial exchanges. It is not the country's officially sanctioned title. A/NZ is increasingly used by the country's socially liberal to designate (a desire for) an emerging bicultural national condition. See Paul Spoonley, 'Constructing Ourselves: The Post-colonial Politics of Pakeha', in M. Wilson and A. Yeatman (eds), Justice and Identity: Antipodean Practices, Bridget Williams Books, Wellington, 1995, pp. 96-115.

6 For one account of these processes see Jane Kelsey, The New Zealand Experiment: A World Model for Structural Adjustment, Auckland University Press and Bridget Williams Books, Auckland, 1997.

Simon During, 'Postcolonialism and Globalization: Towards a Historicization of their Inter-relation', Cultural Studies, 200o, vol. 14, no. 3/4, p. 391.

8 Cited in Kelsey, p. 327.

9 See Ranginui Walker, Struggle Without End: Ka whawhai tonu matou, Penguin, Auckland, 1990.

For a recent collection of essays see Michael Belgrave, Merata Kawharu and David Williams (eds), Waitangi Revisited: Perspectives on the Treaty of Waitangi, Oxford University Press, Melbourne, 2004.

11 The term biculturalism was introduced into the country's academic discourse by Eric Schwimmer, The Maori People in the Nineteen Sixties, Blackwood, Auckland, 1968.

12 Donna Awatere's essentialist Indigenous critique set the agenda for 'race relations' debate in late twentieth century A/NZ. Over this period numerous 'Treaty-oriented' histories have reorganised the country's past-present alignments. See, for example, Anne Salmond, Two Worlds: First Meetings between Maori and Europeans, Viking, Auckland, 1991; James Belich, The New Zealand Wars and the Victorian Interpretation of Racial Conflict, Auckland University Press, Auckland, 1986; Judith Binney, Redemption Songs: A Life of Te Kooti Arikirangi Te Turuki, Auckland University Press, Auckland, 1995.

13 See Spoonley; Aril Bell, 'Authenticity and the Project of Settler Identity in New Zealand', Social Analysis, vol. 43, no. 3, 1999, pp. 122-45.

Wendy Larner and Paul Spoonley, 'Post-colonial Politics in Aotearoa/New

Zealand', in Daiva Stasiulis and Nira Yuval-Davis (eds), Unsettling Settler

Societies, Sage, London, 1995, p. 61.

15 Mark Williams, 'How Many Cultures Make a Culture?', New Zealand Books, October, 1996, p. 12.

16 See Museum of New Zealand-Te Papa Tongarewa Act, Government Printers, Wellington, 1992.

17 Simon Collins, 'Big Bangs for “Disneyland”, City Voice, 10 June 1992.

18 Cheryll Sotheran and Cliff Whiting, 'The Positioning of the Museum of New Zealand Te Tapa Tongarewa', in Museums: A Forum for Museums, Stakeholder Representatives and Marketing Support Agencies: conference proceedings, Waikato Museum, Hamilton, 1995, October 1-3.

19 Cited in Collins.

20 Pete Bossley, Te Papa: An Architectural Adventure, Te Papa, Wellington, 1998. 
21 Ken Gorbey, Report on an Investigatory Trip to Europe and the United States of America, The Museum of New Zealand - Te Papa Tongarewa, Wellington, 1994.

22 Details are reported in 'Themed Attractions Project: Report for the period 1 February 1997 to 28 February 1997', Themed Attractions: Concept and Design Documentation vol. 1, File Number TH35-05, Museum of New Zealand, Wellington.

23 George Ritzer and Allan Liska "McDisneyization" and "Post-tourism": Complementary Perspectives on Contemporary Tourism', in Chris Rojek and John Urry (eds), Touring Cultures: Transformations of Travel and Theory, Routledge, London and New York, 1997, pp. 96-109.

24 Te Papa: Redefining the Word Museum: Tourism Trade Manual 1998-99, Museum of New Zealand Te Papa Tongarewa, Wellington, n.p.

25 Sidney Moko Mead, Te Maori, Maori Art from New Zealand Collections, Harry N. Abrams, New York, 1984.

26 For different contemporary perspectives see those of Maori scholar Sidney Moko Mead, 'Concepts and Models for Maori Museums and Central Centres', AGMANZ Journal, 1985, vol. 16, no. 3, pp. 3-5.

27 James Clifford, The Predicament of Culture: Twentieth-century Ethnography, Literature, and Art, Harvard University Press, Cambridge, MA, 1988, pp. 209-10; Ivan Karp and Steven D. Lavine, 'Introduction: Museums and Multiculturalism', in Ivan Karp and Steven D. Lavine (eds), Exhibiting Cultures: The Poetics and Politics of Museum Display, Smithsonian Institution Press, Washington, 1991, p. 2.

28 Raymond Corbey, 'Ethnographic Showcases, 1870-1930', in J. Nadreveen and B. Parekh (eds), The Decolonization of the Imagination: Culture, Knowledge and Power, Zed Books, Atlantic Highlands, New Jersey, London 1995, p. 71.

29 Nicholas Thomas, Colonialism's Culture: Anthropology, Travel and Government, Melbourne University Press, Melbourne, 1994, p. 184. Stephen Turner offers an important corrective to Thomas's position in 'Sovereignty, or the Art of Being Native', Cultural Critique, vol. 51, 2002, pp. 81-2.

30 Simon During, 'What Was the West?: Some Relations between Modernity, Colonisation and Writing', Meanjin, vol. 48, no. 4, 1989, p. 769; Clifford, pp. 209-10.

31 Te Maori corresponded with the advent of trenchant anti-colonial activism that deemed Maori the only adequate interlocutors for their taonga, radically questioning the legitimacy of Pakeha scholarship. For more see Walker; Paul Tapsell, 'From the Sideline: Tikanga, Treaty Values and Te Papa', in Michael Belgrave et. al., pp. 266-82; Ngapine Allen, 'Maori Vision and the Imperialist Gaze', in Tim Barringer and Tom Flynn (eds), Colonialism and the Object, Routledge, New York, 1998, pp. 144-52.

32 Tapsell defines whakapapa as 'a systematic framework ordering descendants under common ancestors; genealogical descent lines connecting gods with all things living'. Paul Tapsell, 'The Flight of Pareraututu: an Investigation of Taonga from a Tribal Perspective', Journal of the Polynesian Society, 1997, vol. 106, no. 4, p. 326.

33 Rosemary McLeod, 'The Mighty MoNZ: Artless at Heart?', North and South, October, 1994, p. 76.

34 Nga Taonga o Te Motu: Treasures of the Nation: National Museum of New Zealand: Te Marae Taonga o Aotearoa: A Plan for Development, Report of the Project Development Team, Wellington, November 1985, p. 7. Here, on the one hand, a 'nationalised' Maoriness looked to provide a suitable export image for a cosmopolitan gaze and one around which a renovated settler nationalism could cohere. On the other hand, such Maoriness gave Indigenous communities unprecedented access to an international stage for self-representation and a 
certain cultural capital to exploit.

Museum of New Zealand-Te Papa Tongarewa: Report on the Interviews, 22 September 1988, p. 9.

36 A Concept for the Museum of New Zealand Te Papa Tongarewa, adopted by the Project Development Board at its meeting held on 4 April 1989, Wellington. For an analysis of early commentary on the museum's conceptual architecture see Ben Dibley, 'Museum, Nation, Narration', Culture and Policy, vol. 8, no. 3, 1997, pp. 97-118.

37 Bossley, Te Papa: An Architectural Adventure. Pete Bossley, 'The Treaty,' Architecture New Zealand, 1998, February, pp. 64-7.

38 See Te Papa: Annual Report, 1 July 1997 - 30 June 1998, Museum of New Zealand, Wellington.

39 Sotheran cited in Dibley, 'Museum, Nation, Narration', p. 105.

40 Lorenzo Veracini and Adrian Muckle, 'Reflections of Indigenous History inside the National Museums of Australia and Aotearoa New Zealand and outside of New Caledonia's Centre Culturel Jean-Marie Tjibaou', The Electronic Journal of Australian and New Zealand History, 2002. Also see Neill, and Williams.

See Nick Perry, 'Upside Down or Downside Up? Sectoral Interests, Structural Change and Public Policy', in John Deeks and Nick Perry (ed.), Controlling Interests: Business, the State and Society in New Zealand, Auckland University Press, Auckland, 1992. Cited in 'Time to Delay Museum Plans', The Evening Post, 28 February 1991. Brian Rudman, 'Another Grandiose Monument to Insanity', Sunday Star, 31 May 1992; 'Think Big Reincarnate', New Zealand Herald, 29 May 1992.

44 Rudman.

45 Apirana Mahuika, 'Maori Culture and the New Museum', Museum Anthropology, vol. 15, no. 4, 1992, pp. 9-11.

46 Ibid.

47 Tapsell, Taonga, pp. 156-217, 179.

48 Both Te Ati Awa and Ngati Toa had claims before the Waitangi Tribunal, which argued 'that the aboriginal title to Wellington's reclaimed harbour-front [on which the Museum stands] has never been extinguished by the Crown and that it continues to belong to the tangata whenua', Tapsell, Taonga, p. 179.

49 Bieringa, pp. 11-2.

50 Wedde, 'Museum of New Zealand: Te Papa Tongarewa', p. 43.

51 Bolger cited in The Evening Post, 27 July 1994.

Micheal Volkerling, The First Fifty Years: The State, Leisure and the Arts in New Zealand since 1945, Auckland University Winter Lecture Series, unpublished manuscript, 1995, pp. 5, 4. Also see Michael Volkerling, 'Death or Transfiguration: The Future for Cultural Policy in New Zealand', Culture and Policy, 1994, no. 6, pp. 7-28.

53 Volkerling, The First Fifty Years, p. 13.

54 Sotheran cited in Newsletter: Museums Association of Aotearoa New Zealand, Te Ropa Hanga Kaupapa Taonga, 1997, vol. 6, no. 2, n.p.

55 Volkerling, The First Fifty Years, p. 13.

56 See Colmar Brunton, What Keeps Them Coming: Visitor Satisfaction Research Quantitative Report, Museum of New Zealand, Wellington, 1998. For qualitative findings see Lisa McCauley, Customer Satisfaction: Findings from the Qualitative Research Conducted at Te Papa-May 1998, Museum of New Zealand, Wellington, 1998.

57 The phrase belongs to Chris Rojek. Chris Rojek, Ways of Escape, MacMillan, London, 1993, p. 205. The Dominion, 20 August 1998. 
59 'Te Papa like supermarket, says Swiss architect', West Coast Times, 13 August 1998.

6o See Chris Watson, Te Papa Post Occupancy Evaluation for the Visitor Communications Group, C. Watson Consultancy, Wellington, 1998, p. 131.

Nathalie Hienich's analysis of the Georges Pompidou Centre reflects on the relation between drifting and anxiety. Natalie Heinrich, 'The Pompidou Centre and its Public: The Limits of a Utopian Site', in Robert Lumley (ed.), The Museums Time Machine, Routledge, London, 1988, pp. 199-212.

61 Jenny Forsyth, 'Te Papa "a Terrible Warning to World”, New Zealand Herald, 3 March 2000.

62 Ian Wedde, 'Our Place in the World', New Zealand Listener, 14 February 1998, p. 26.

63 Hamish McDonald, 'Playing with History', Sydney Morning Herald, 11 July 1998, p. 7 .

64 Fredric Jameson, 'Postmodernism or the Cultural Logic of Late Capitalism', New Left Review, 1984, no. 146, p. 84.

65 Henare, p. 60.

66 Jenny Harper, 'For the Sake of Your Art', The Dominion, 2 June 1998, p.10.

67 Williams, p. 21.

68 Božiċ-Vrbančić, pp. 312, 313

69 Henare, p. 59.

70 Neill, pp. 183-85; Božiċ-Vrbančić, p. 313.

71 Paul Walker and Justine Clark, 'Museum and Archive: Framing the Treaty', in Anna Smith and Lydia Wevers (eds), On Display: New Essays in Cultural Studies, Victoria University Press, Wellington, 2004, pp.163-79.

72 Henare, p. 60.

73 Perry, 'Antipodean Camp', 18.

74 Ann French, 'Setting Standard', Architecture New Zealand, 1998, February, p. 70.

75 Bossley, 'The Treaty', p. 64-7.

76 Michel Foucault, The Archaeology of Knowledge, Routledge, London, 1989, p. 7.

77 Walker and Clarke, pp. 169-72.

78 Božic̀-Vrbančić, p. 313; Williams, p. 21.

79 Walter Benjamin, 'The Work of Art in the Age of Mechanical Reproduction', in Illuminations, Fontana, London, 1973, p. 234; Jameson, pp. 76-7.

8o See Jonathan Lamb, 'The New Zealand Sublime', Meanjin, vol. 49, no. 4, 1990, pp. 663-75.

81 Perry, 'Antipodean Camp', 13. This is also suggested by the title of Chris Healy's book in which he offers his own antipodean permutation on the angel allegory. Chris Healy, From the Ruins of Colonialism: History as Social Memory, Cambridge University Press, Cambridge, 1997, p. 6.

82 Denis Dutton, 'New National Museum Resembles a Junkshop,' New Zealand Herald, 21 May 1998, p. 15. 